\title{
PROGON SRBA IZ ZAGREBA I ODUZIMANJE SRPSKE IMOVINE 1941. GODINE
}

\begin{abstract}
APSTRAKT: Autor u radu donosi podatke o prisilnom iseljavanju Srba iz Zagreba 1941. godine. Na temelju izvornog arhivskog gradiva i relevantne literature obrađena su tri vala progona Srba iz Zagreba koja su se odvijala u srpnju 1941. U prva dva vala iz Zagreba je protjerana 261, odnosno 80 osoba. Srbi koji su uhapšeni u prva dva vala protjerani su direktno u Srbiju, dok su Srbi iz trećeg vala prvo deportirani u logor Caprag, a potom iz njega, njih 343, u Srbiju. Uz one koji su pojedinačno iselili ukupan poimenični popis protjeranih može obuhvatiti 951 osobu. Jedan manji broj Srba uspio je putem molbi izaći iz logora u Capragu. Evidentno je da taj popis nije potpun i da je prognanih u svakom slučaju bilo više. Što se srpske imovine tiče, iz dokumenata je vidljivo da je ona bila velikim dijelom podržavljena, ali da su pojednci, uz pomoć prijateljskih i poslovnih veza, uspijevali zadržati svoju imovinu. Razmjere podržavljenja te imovine nije u potpunosti moguće utvrditi, ali ako je vjerovati statistikama koje su provele državne vlasti, čini se da je najmanje 95 srpskih poduzeća i 86 srpskih zgrada u Zagrebu bilo podržavljeno.
\end{abstract}

Ključne riječi: Drugi svjetski rat, 1941, Srbi, Nezavisna Država Hrvatska, Zagreb, koncentracioni logori

\section{Uvod}

Prije 1781. bilo je tek pojedinačnih pojavljivanja (dolazaka i boravaka) pravoslavnih u Zagrebu. Od patenta o toleranciji Josipa II 1781. godine dolazi i do pravog naseljavanja Srba u Zagreb. Tu povlasticu odmah su iskoristili trgovci, koji su se i ranije počeli na- 
stanjivati u Zagrebu, iako njihov položaj nije bio pravno reguliran. Broj pravoslavnih, koji u vrijeme prvih doseljavanja nisu bili podrijetlom samo iz Srbije, raste $s$ vremenom doseljavanjem novih obitelji. U godini 1785. Zagreb ima osam pravoslavnih domova sa 40 duša, 1792. dvanaest domova i 71 duša, dok 1821. u 19 domova živi 158 duša i to 95 Srba, 48 Grka i 15 Cincara. ${ }^{1}$ U popisu domova pravoslavnih stanovnika grada iz 1806. godine, koji sadrži 59 brojeva, spominje se najviše trgovaca, jedan doktor, deset obrtnika i raznih udovica. Prema istraživanjima Dimitrija Vitkovića vidljivo je da je oko 1821. među pravoslavnima bilo oko 60\% Srba, $25 \%$ Grka i $15 \%$ Cincara. ${ }^{2}$ Broj Grka i Cincara se do 1850 . sveo na $5 \%$, što pokazuje da se pravoslavna zajednica iz jedne etnički nekoherentne zajednice pretvorila u urbanu integriranu i nacionalno svjesnu grupu. ${ }^{3}$ Od tada do Drugog svjetskog rata broj pravoslavnih u Zagrebu konstantno raste.

Broj pravoslavnih u Zagrebu prema popisima stanovništva ${ }^{4}$

\begin{tabular}{|r|r|r|}
\hline Godina & $\begin{array}{c}\text { Broj pravoslavnih u } \\
\text { Zagrebu }\end{array}$ & $\begin{array}{r}\text { Ukupan broj stanovnika } \\
\text { Zagreba }\end{array}$ \\
\hline 1857. & $332(2,5 \%)$ & 13.083 \\
\hline 1869. & $582(2,9 \%)$ & 19.857 \\
\hline 1880. & $959(3,7 \%)$ & 25.825 \\
\hline 1890. & $1.204(3,2 \%)$ & 37.529 \\
\hline 1900. & $2.712(4,4 \%)$ & 61.002 \\
\hline 1910. & $4.074(5,9 \%)$ & 69.209 \\
\hline 1921. & $9.293(8,5 \%)$ & 108.674 \\
\hline 1931. & $13.279(7,2 \%)$ & 185.581 \\
\hline
\end{tabular}

1 D. Roksandić, „Pravoslavna crkvena općina na području Gradeca između patenta o toleranciji 1781. i revolucije 1848/9. godine", Zagrebački Gradec 1242.-1850., Zagreb, 1994, str. 287.

2 V. Cvjetković Kurelec, "Grci na Gradecu krajem 18. i početkom 19. stoljeća", Zagrebački Gradec 1242.-1850., Zagreb, 1994, str. 306.

3 D. Vitković, Srpska pravoslavna crkvena općina, parohija i škola u Zagrebu, Hronologijsko-istorijski pregled, Zagreb, 1985, str. 119.

4 Podaci su preuzeti iz: Statistische übersichten über die Bevölkerung und den Viehstand von Östereich nach der zählung vom 31. october 1857, Wien, 1859; Ergebnisse der in den Landern der ungarischen krone am anfage des jahres 1870 vollzogenen Volkszaehlung samt nachweisung der nutzbaren hausthiere, Pest, 1871, 66; HDA, Zavod za statistiku, fond 367, kutija 5, fascikl 6, Grad Zagreb po ulicama: stanovništvo prema materinjem jeziku u kombinaciji sa vjeroispovijesti i dobi žiteljstva; Političko i sudbeno razdieljenje kraljevina Hrvatske $i$ Slavonije $i$ repetitorij mjesta (1880), Zagreb, 1889; HDA, Zavod za statistiku, fond 367, kutija 10, fascikl 15, Popis prema materinjem jeziku i vjeri, popis 1890 . g. i Političko i sudbeno razdieljenje Kraljevina Hrvatske i Slavonije - Repetitorij mjesta po po- 
Podrijetlo zagrebačkog stanovništva 1931. godine po ondašnjim banovinama ${ }^{5}$

\begin{tabular}{|l|r|r|}
\hline Banovina & Broj stanovnika & $\begin{array}{l}\text { Postotak od ukupnog } \\
\text { broja stanovnika }\end{array}$ \\
\hline Savska & 131.215 & 70,70 \\
\hline Dravska & 17.541 & 9,45 \\
\hline Primorska & 5.050 & 2,72 \\
\hline Drinska & 3.236 & 1,74 \\
\hline Vardarska & 668 & 0,36 \\
\hline Zetska & 1.198 & 0,65 \\
\hline Dunavska & 4.523 & 2,43 \\
\hline Moravska & 660 & 0,35 \\
\hline Vrbaska & 2.636 & 1,42 \\
\hline Uprava grada Beograda & 854 & 0,46 \\
\hline Ukupno & 167.581 & 90,30 \\
\hline
\end{tabular}

Dakle, pred Drugi svjetski rat u gradu Zagrebu moglo je biti oko 15.000 pravoslavnih, od kojih su najveći postotak činili upravo Srbi.

\section{Godina 1941.}

Uspostavom Nezavisne Države Hrvatske 1941. godine počelo je najtragičnije razdoblje u povijesti srpskog naroda u Hrvatskoj. ${ }^{6}$ Genocidni ustaški plan sa Srbima sveo se na takozvanu teoriju "o trećinama". Jednu trećinu Srba trebalo je protjerati, jednu trećinu

sljednih popisa godine 1890, Zagreb, 1892; Popis žiteljstva od 31. prosinca 1900 u kraljevinama Hrvatskoj i Slavoniji, Zagreb: Kraljevski zemaljski statistički ured, 1914; HDA, Zavod za statistiku, fond 367, kutija 40, fascikl 53, Županije po upravnim općinama i prebivalištima te grad Zagreb po kotarima - ulicama - glavni rezultati popisa prema vjeroispovijesti, materinjem jeziku, dobi i naobrazbi 1910; HDA, Zavod za statistiku, fond 367, kutija 55, fascikl 70, Prisutno stanovništvo prema vjeroispovjedi i materinjem jeziku, popis 1931; Definitivni rezultati popisa stanovništva od 31. marta 1931. u Kraljevini Jugoslaviji, knjiga II, Prisutno stanovništvo po veroispovesti, Beograd: Direkcija državne statistike, 1938.

Podaci su preuzeti iz: A. Laušić, Utjecaj migracija na rast stanovništva grada Zagreba do godine 1948, Zagreb, 1989, str. 52.

5 Podaci su preuzeti iz: A. Laušić, Utjecaj migracija na rast stanovništva grada Zagreba do godine 1948, Zagreb, 1989, str. 52.

6 U NDH prema vjeri od ukupno 5.655.750 žitelja bilo je 2.993 .335 ili 52,93\% rimokatolika, 772.794 muslimana $(12,78 \%), 1.809 .613$ pravoslavnih $(31,99 \%), 59.281$ evangelik (1,05\%) i 32.372 Zidova (0,57\%). Izračun je za osnovu uzimao jugoslavenski popis stanovništva od 31. ožujka 1931. kojemu je dodan prirodni priraštaj (R. Landikušić, Priručnik o političkoj i sudbenoj podjeli NDH, Zagreb, 1942, str. 13). Brojevi stanovništva variraju u drugim publikacijama iz onoga vremena. 
poubijati, a jednu trećinu pokrstiti. Ta teorija nikada nije zapisana u ustaškim programskim spisima niti je zabilježena u tisku NDH, ali je činjenica da je ustaški teror nad Srbima za cilj imao teoriju o trećinama. Tako je Herman Neubacher, povjerenik za Jugoistok sa sjedištem u Beogradu, tvrdio da Pavelićeva formula o trećinama podsjeća na istrebljivanja u vrijeme "vjerskih ratova u najkrvavijim vremenima", te je zaključio kako je posljednja točka programa - ona o ubijanju - u vrijeme dok je on to pisao, ujesen 1943. godine, „već provedena". ${ }^{7} \mathrm{U}$ prvom periodu nakon osnutka NDH ustaški režim želio se osvetiti svim "neprijateljima" koji su na bilo koji način sudjelovali ili podržavali bivši kraljevski režim i bili "neprijatelji hrvatskog naroda". Prvi na koje se ustaški režim okomio bili su Srbi. ${ }^{8}$ Već 11 . travnja 1941 . godine u listu Hrvatski narod najavljeno je da će "pravedni hrvatski narod suditi ne samo našim vjekovnim neprijateljima Srbima i Srbijancima nego i onim pripadnicima nove Hrvatske, koji su svjesno i zlonamjerno pomagali ove naše neprijatelje". ${ }^{9}$ Sedam dana nakon uspostave NDH doneseni su propisi koji su ozakonili teror i odredili državne institucije koje će teror provoditi. Tako je već 17. travnja 1941. donesena Zakonska odredba za obranu naroda i države. ${ }^{10}$ Njome se utvrdilo da svatko "tko na bilo koji način povrijedi ili je povrijedio čast i životne interese hrvatskog naroda ili bilo na koji način ugrozi opstanak NDH ili državne vlasti, pa makar djelo ostalo samo u pokušaju, čini se krivcem zločinstva veleizdaje", a takvoga "ima stići kazna smrti".

Dana 25. travnja 1941. godine Pavelić je izdao Zakonsku odredbu o zabrani ćirilice. ${ }^{11}$ Vrlo brzo nakon toga, 3. svibnja 1941, Pavelić je donio Zakonsku odredbu o prijelazu s jedne vjere na drugu. Početkom lipnja donesena je odredba o ukidanju svih "srpsko-konfesionalnih pučkih škola i zabavišta", a sredinom srpnja izdana je naredba o ukidanju naziva "srpsko-pravoslavna vjera" s obrazloženjem da nije više u skladu s novim državnim uređenjem, pa se određuje da

I. Goldstein, Hrvatska 1918.-2008., Zagreb, 2008, str. 258-259.

8 O odnosu prema Srbima u NDH vidjeti u: I. Goldstein, Hrvatska 1918.-2008., Zagreb, 2008, str. 256-271, F. Jelić-Butić, Ustaše i NDH, Zagreb, 1978, str. 158-187, B. Krizman, Pavelić između Hitlera i Mussolinija, Zagreb, 1980, str. 117-137, HoryBroszat 1965; N. Bartulin, "Ideologija nacije i rase: ustaški režim i politika prema Srbima u Nezavisnoj Državi Hrvatskoj 1941-1945", Radovi Zavoda za hrvatsku povijest Filozofskog fakulteta u Zagrebu, sv. 38 (2007), str. 209-242.

9 Hrvatski narod, 11. travnja 1941.

10 O zakonskoj odredbi za obranu naroda i države vidjeti više u: Zakoni NDH, I, Zagreb, 1941, str. 15; Hrvatski narod, 18. travnja 1941; I. Goldstein, Holokaust u Zagrebu, Zagreb, 2001, str. 117.

11 Narodne novine, 25. travnja 1941. 
se u buduće upotrebljava naziv "grčko-istočna vjera". Ustaške su vlasti prvo otpustile veliki broj Srba koji su bili zaposleni u Zagrebu. Konkretne mjere za protjerivanje srpskog stanovništva iz Zagreba neposredno nakon proglašenja NDH poslužile su ustašama kao uzor za daljnji rad. Redarstveno ravnateljstvo je naredbom od 7. svibnja 1941. zapovijedilo progon svih Židova i Srba iz sjevernih dijelova grada Zagreba. ${ }^{12} \mathrm{O}$ iseljavanju srpskih stanova sjevernog dijela grada postoji niz dokumenata u Državnom arhivu Zagreb. Iz popisa iseljenih stanova je vidljivo da je bilo mnogo više židovskih objekata nego srpskih. Prema prezimenima je najčešće moguće odrediti da li je pojedini stan ili objekt židovski ili srpski. ${ }^{13}$ Tako je jedan dio Srba prognan iz boljih dijelova grada u siromašnije dijelove južno od pruge. ${ }^{14}$ Čini se da je južni dio grada trebao biti podijeljen u tri zone te da su u jednoj zoni trebli biti nastanjeni Srbi i Židovi tako da bi im se suzilo područje u kojem su do tada živjeli, što je zapravo značilo stvaranje svojevrsnog geta. ${ }^{15}$ U gradu Zagrebu ispražnjeno je do 16 . svibnja 577 stanova i kuća u sjevernom dijelu grada. ${ }^{16}$ Dakako, radilo se o stanovima za koje su bili zainteresirani ustaški funkcionari, dok su ostali stanovi i kuće iseljeni nakon protjerivanja Srba iz Zagreba u logor Sisak. I druga odredba od 7. svibnja 1941. također je pogodila i Srbe (osim Židova) u Zagrebu. Tako su se Srbi mogli kretati Zagrebom samo danju od 9 ujutro do 6 popodne. Istom je odredbom određeno Srbima da ne smiju izlaziti iz grada bez posebnih propusnica i da ne smiju ulaziti u grad (oni koji su bili naseljeni izvan njega).

U Zagrebu je 4. lipnja 1941. godine organiziran sastanak u njemačkom veleposlanstvu između njemačkog predstavnika u NDH i vlasti $\mathrm{NDH}$, na kojem su Siegfried Kasche, njemački veleposlanik u NDH, i Slavko Kvaternik, doglavnik, potpisali sporazum o razmjeni pučanstva i to tako da se Slovenci nasele u NDH, a Srbi iz NDH u Srbiju. Trebalo je biti prognano blizu 100.000 Srba. NDH je za provedbu dogovora od 4. lipnja osnovala Državno ravnateljstvo za ponovu 20. lipnja. Dana 7. lipnja 1941. posebnom naredbom pozvani su Srbi koji su se doselili na područje NDH poslije 1 . siječnja 1900. godine te njihovi potomci da se

\footnotetext{
12 Hrvatski narod, br. 87, 10. svibnja 1941, str. 5.

13 DAZ, Gradsko poglavarstvo Zagreb, fond br. 24, Stambeni ured (1941-1943), popis vlasnika stanova i stanara u Zagrebu prema kartoteci osiguravajućih društava) i HDA, Državno ravnateljstvo za ponovu, Stanovi i zgrade, kutija 1742.

14 I. Goldstein, "Nezavisna Država Hrvatska 1941. godine: put prema katastrofi", Dijalog povjesničara/istoričara, sv. 10/1, Zagreb, 2008, str. 142-143.

15 Hrvatski narod, br. 91, 14. svibnja 1941, str. 9.

16 Hrvatski narod, br. 94, 17. svibnja 1941, str. 11.
} 
u roku od deset dana prijave vlastima u mjestu svojega boravišta. To je bila naredba kojom se pravio popis onih koji su se najprije trebali protjerati, a takvih je Srba u Zagrebu bilo mnogo, budući da su tijekom međuratnog perioda doseljavali u grad (i na područje Hrvatske i Bosne i Hercegovine) zbog zaposlenja. ${ }^{17}$ Državno ravnateljstvo za ponovu je već 2 . srpnja poslalo dopise svim velikim župama o uspostavljanju ureda za iseljavanje na vlastitu području u svakom kotaru. Na čelu toga ureda imao je biti kotarski predstojnik. Svaki kotar je morao primiti 2.500 Slovenaca, bez obzira na to koliko je u njemu živjelo Srba. ${ }^{18}$ Dakako da Slovenci nisu primljeni u Zagrebu, već samo u srpskim selima. Naime, srpsku imovinu u Zagrebu prigrabili su uglavnom ustaški dužnosnici ili njihovi simpatizeri.

\section{Popisivanje Srba u Zagrebu i prva hapšenja}

Ustaške su vlasti preko Državnog ravnateljstva za ponovu popisivale Srbe u Zagrebu. Sasvim je očito da su postojali poimenični popisi svih Srba u Zagrebu budući da su hapšenja koja će slijediti izvedena vrlo precizno i ciljano. Tako su na primjer posebno popisani liječnici Srbi, kojih je u Zagrebu bilo četrdeset i jedan, a njihove kuće i ordinacije uglavnom su bile smještene na atraktivnim lokacijama (Svačićev trg 13, Mesnička 7, Tomislavov trg 20, Trenkova 7, Preobraženska 2, Bogovićeva 2, Mihanovićeva 3, Gundulićeva 36...). ${ }^{19}$ Slično je popisano i 16 odvjetnika koji su "grčko-istočne vjere". Popisani su i svi trgovci, industrijalci, trgovački zastupnici, bankari, apotekari i obrtnici, njih 94. Uz njih stoje informacije na kojim adresama im se nalaze radnje, stanovi, da li imaju posjede, kojim se obrtom bave, da li posjeduju dionice, da li su članovi zadružnog osiguranja (da li posjeduju životno osiguranje ili osiguranje nekretnina), kolika je vrijednost inventara njihove radionice i kolika je ukupna vrijednost njihove imovine. Iz popisa je vidljivo da su informacije o pojedincima pažljivo prikupljene i da se uglavnom radi o bogatim pojedincima za čiju su imovinu, sasvim očito, ustaške vlasti

17 F. Jelić-Butić, Ustaše i NDH, Zagreb, 1978, str. 167-168.

18 A. Lj. Lisac, "Deportacije Srba iz Hrvatske 1941", Historijski zbornik, 1956, str. 127; I. Goldstein, "Iseljavanje Srba i useljavanje Slovenaca u Nezavisnoj Državi Hrvatskoj 1941. godine", Vojetov zbornik, Med Srenjo Evropo in Sredozemljem, Ljubljana, 2006, str. 595-605; I. Goldstein, Hrvatska 1918.-2008., Zagreb, 2008, str. 260-261; S. D. Milošević, Izbeglice i preseljenici na teritoriji okupirane Jugoslavije 1941-1945, Beograd, 1981, str. 135.

19 HDA, Državno ravnateljstvo za ponovu, kutija 441, 224/41. 
imale interes. ${ }^{20}$ Usko vezano uz popisivanje Srba u Zagrebu bilo je i otpuštanje Srba iz državnih službi. Naime, već 10. svibnja 1941. izdana je naredba Ministarstva unutrašnjih poslova NDH u kojoj se navodi da se iz službe moraju otpustiti svi Srbijanci i Crnogorci. Od ostalih Srba trebalo je otpustiti one koji su se isticali svojim radom protiv interesa hrvatskog naroda. Jedan je dio Srba i dalje zadržan na svojim radnim mjestima, ali više nisu mogli ostati na vodećim položajima. U Zagrebu je velik broj Srba bio zaposlen na željeznicama. Veći broj njih, budući da su bili u najvećem postotku Srbijanci, bio je otpušten. ${ }^{21}$ Već 20. travnja 1941. poduzeta su prva hapšenja u Zagrebu. "Zagrebačko redarstvo u uskoj suradnji sa odsjekom za javni red i sigurnost, izvršilo je niz uhapšenja, raznih nepoćudnih osoba, koje ugrožavaju sigurnost u gradu Zagrebu, odnosno koje su se ogriješile o interese hrvatskog naroda. Ovlašteni smo napisati da se medju uhapšenima ne nalaze žene ni malodobnici uopće i da se sa svima postupa strogo po zakonu." 22 Među uhapšenima nalazio se i određeni broj Srba. O tome svjedoči i činjenica da je jedan od uhapšenih bio Branko Lazarević, činovnik iz Zagreba. Hapšenja su vrlo često masovna, a tek ponekad se iznose brojke. Tako 9. svibnja 1941. u Hrvatskom narodu stoji brojka od uhapšenih 114 četnika i ljudi koji su s njima u vezi u Zagrebu. ${ }^{23}$ Među uhapšenima u svibnju i lipnju 1941. nalazili su se i istaknutiji Srbi poput mitropolita Dositeja, podbana Tome Bošnjaka, industrijalca Ozrena Bačića, dr Nikole i Branka Mrvoša, suca Mikašinovića i banskog savjetnika Joce Maksimovića. ${ }^{24}$ Većina njih je završila u Kerestincu, a potom u Jadovnom. Činjenica je da je prema poimeničnom popisu žrtava logora Jadovno iz Zagreba likvidirano 460 osoba, od toga 77 Srba. ${ }^{25}$ Pojedinci su se odupirali hapšenjima. Dušan Zelenbaba, glavni

20 HDA, Državno ravnateljstvo za ponovu, kutija 456.

21 S. D. Milošević, Izbeglice i preseljenici na teritoriji okupirane Jugoslavije 19411945, Beograd, 1981, str. 131.

22 Hrvatski narod, br. 68, 21. travnja 1941, str. 4.

${ }^{23}$ Hrvatski narod, br. 86, 9. svibnja 1941, str. 6.

24 HDA, ZKRZ-ZH, kutija 486, 37578-37579 (Zapisnici o preslušanju Srba koji su otišli u Srbiju).

25 Đ. Zatezalo, Jadovno, kompleks ustaških logora 1941, Beograd, 2007, str. 584598. Vidjeti i iskaz Koste Jugovića, glavnog knjigovođe Srpske banke u Zagrebu, HDA, ZKRZ-ZH, kutija 486, 37578-37579. Prema istraživanjima Zdravka Dizdara, kroz logor Danica je prošlo 57 Srba, od kojih je jedan dio stradao u Jadovnom i u logoru Slana. (Z. Dizdar, "Ljudski gubici logora 'Danica' kraj Koprivnice 1941.1942.", Časopis za suvremenu povijest, god. 34 (2002), sv. 2, str. 389). Prema istraživanjima kustosa iz Spomen-područja Jasenovac iz grada Zagreba stradalo je tijekom sve četiri godine postojanja logora 1.775 osoba. Od toga ih je 1.159 bilo Židova, 448 Hrvata, 91 Roma, 46 Srba, 17 Slovenaca i 14 ostalih. Za podatke se zahvaljujem kustosu Spomen-područja Jasenovac gospodinu Đorđu Mihoviloviću. 
kuhar u Esplanadi, odupro se hapšenju 26. svibnja 1941. koje su željeli provesti ustaše, pa je na njih ispalio šest metaka. Nakon hapšenja predan je Prijekom sudu. ${ }^{26}$ Vidljivo je da je vrlo brzo, 30. svibnja, strijeljan. ${ }^{27}$ Proglas u Hrvatskom narodu od 25. travnja 1941. otkriva da se u Zagrebu nalazio veći broj pripadnika bivše Jugoslavenske kraljevske vojske. Oni su se krili po stanovima, pa je Zapovjedništvo kopnene vojske Hrvatske pozvalo građane grada Zagreba da prijave takve slučajeve te da će potom takvi biti uhapšeni, a zatim sprovedeni u Ilicu 242 kao ratni zarobljenici. Ističe se da su takvi časnici i vojnici po narodnosti Srbi podrijetlom iz Srbije, Crne Gore i Makedonije. ${ }^{28} \mathrm{Da}$ bi se lakše mogla izvršiti hapšenja, ustaški povjerenik za javni red i sigurnost u Zagrebu Božo Cerovski donio je odredbu da svi kućevlasnici moraju prijaviti svoje podstanare pod prijetnjom teških posljedica. ${ }^{29}$

\section{Progon Srba iz Zagreba}

Odmah nakon prvih popisivanja, otpuštanja i hapšenja, uslijedili su progoni Srba iz Zagreba. Nije neobično da su se progoni dogodili u izuzetno kratkom roku nakon uspostave Državnog ravnateljstva za ponovu. Naime, hapšenje i progon Srba iz Zagreba trebali su biti generalna proba za hapšenja i progon Srba iz ostalih gradova i sela NDH. Tako su prva hapšenja obavljena 5. i 6. srpnja 1941. godine. Kako su hapšenja izgledala saznajemo naknadno iz dopisa uhapšenika. Tako inženjer Dušan Stojanović piše u svojem dopisu Državnom ravnateljstvu za ponovu 3. kolovoza iz Beograda kako su 5. srpnja oko 6 sati ujutro, bez ikakvog razloga i uz napomenu da idu na preslušanje te da će se kroz pola sata vratiti kući odvedeni iz njihova doma u Trebinjskoj 3. "Odlazeći nijesmo apsolutno ništa sobom uzeli. Odvedeni smo na pola goli i u kućnim papučama, šta više, nijesam stigao uzeti niti umjetno zubalo, bez kojega ne mogu biti." ${ }^{30}$ Sličan iskaz dao je Komesarijatu za izbeglice i preseljenike Ministarskog saveta Milana Nedića u Beogradu krajem 1941. i Nikola Simeunović, protojerej i sekretar crkvenog suda Eparhije zagrebačke: „Dana 5. jula 1941. godine u subotu u 2 sata u noći došli su u moj stan Ilica broj $7 / 3$ sprat 8 naoružanih ustaša

26 Hrvatski narod, br. 106, 29. svibnja 1941, str. 12.

27 Hrvatski narod, br. 108, 31. svibnja 1941, str. 3.

28 Hrvatski narod, br. 72, 25. travnja 1941, str. 2.

29 Isto, str. 6.

30 HDA, Državno ravnateljstvo za ponovu, kutija 455, 4800/41. 
sa jednim svojim ustaškim oficirom, čija mi imena nisu poznata i naredili meni, supruzi i sinu, da odmah ustanemo iz kreveta i da se spremimo za 5 minuta, naredivši, da uzmemo sa sobom samo sav novac i dragocjenosti, te da iziđemo van sa njima gde su nas strpali u zatvoreni auto i odvezli u zagrebački zbor gde su se nalazili ostali Srbi većinom intelektualci isto tako pohvatani. Tu su nas pregledavali i oduzeli nam dragocjenosti i novac, ostavivši nam svakom po 500 dinara: a u toku celog dana doterivani su ostali Srbi po ustašama, a sva naša imovina je ostala u stanu i mi smo otišli i ostali bez igde ičega. U zboru smo izbezumljeni od straha ostali ceo dan do 1 sat u noći bez hrane. Tada su nas oko 193 svrstali u redove i pod jakom ustaškom naoružanom stražom doterali na železničku stanicu Kolodvor Sava u Zagrebu i smestili u marvene vagone. To je bila prva partija proteranih Srba iz Zagreba. (...) U tim vagonima bili smo više od 1 sata. dok nas nije Nemačka vojska premestila u svoje civilne vagone, i onda smo krenuli sa vozom za Sisak-Brod-Sarajevo-Višegrad-Kraljevo, tu smo bili predani od Nemaca srpskim vlastima odakle smo se razbegli svaki na svoju stranu." ${ }^{11}$ Slične su iskaze nakon rata davali Zemaljskoj komisiji za utvrđivanje zločina okupatora i njihovih pomagača i drugi Srbi iz Zagreba koji su prognani. Tako je npr. Zorka Jovanović iz Zagreba opisala svoje hapšenje: „Došla su u moj stan dvojica ustaških agenata u civilu i izdali nalog da smjesta napustimo stan i da ih slijedimo. Ti su agenti došli u stan na najbezobrazniji način, sa revolverom u rukama, i nijesmo uspjeli ni da se čestito obučemo, već smo morali na njihovu zapovjed odmah izaći iz stana i otići u Zvonimirovu ulicu i tu smo ukrcani u kamion skupa sa ostalim pohvatanim pravoslavcima, i odvedeni na Zagrebački zbor. (...) Nakon što smo bili na opisani način izbačeni iz stana, odnesen nam je iz istoga čitav namještaj sa svim ostalim predmetima koji su se u njemu nalazili. Do danas nisam mogla ustanoviti tko je ušao u moj stan i tko ga je opljačkao, jer smo mi sve do sada boravili kao izbjeglice u Beogradu." 32 I Bogoljub Bratić iz Zagreba,

31 HDA, ZKRZ-Zh, kutija 486, 37578-37579. Nakon hapšenja pravoslavnih svećenika u Zagrebu je ostao jedino pravoslavni svećenik, po nacionalnosti Rus, Serafim Kupčevski.

32 HDA, ZKRZ-ZH, kutija 245, 11599/45. Iste su takve iskaze dali i Svetlana Mihletić iz Palmotićeve 15 koja je uhapšena zajedno sa svojom majkom i sestrom (HDA, ZKRZ-ZH, kutija 287, 16399-16401/45), Tanasije Adamović koji je iseljen sa suprugom i dvoje djece iz Šenoine 25, a čija je žena od boravka u logoru Caprag živčano oboljela (HDA, ZKRZ-ZH, kutija 338, 22792-22793/46), Jelena Vukašinović s dvoje djece iz Ilice 204 (HDA, ZKRZ-ZH, kutija 486, 38498/46), Simo Ivković iz Masarykove ulice 16 u čiji se stan uselio Ivo Meniga koji mu je navodno spalio čitavu vrijednu knjižnicu (HDA, ZKRZ-ZH, kutija 486, 38503/46), Dimitrije Selaković (HDA, ZKRZ-ZH, kutija 486, 38503, C.G.K., 618/17), Ljubica Drakulić iz Jurišićeve 4 (HDA, 
nastanjen u Grani 61, uhapšen je 5. srpnja. Ni njemu nisu dozvolili da ponese sa sobom bilo kakve predmete. Ipak, njegova je supruga, par dana nakon što je on već prebačen u Beograd, otišla do stana koji je bio zapečaćen i ondje joj je ustaško redarstvo isporučilo 50 kilograma odjevnih predmeta. ${ }^{33}$ Tako je odvođenje na Zagrebački zbor vjerojatno izgledalo i u drugim slučajevima. U prvom naletu 5. i 6. srpnja 1941. prognana je u Srbiju 261 osoba. Prema strukturi prognanih vidljivo je da se radilo o zaposlenim Srbima. ${ }^{34}$

Iz dokumenata koji su sačuvani u Hrvatskom državnom arhivu vidljivo je da je trebalo biti protjerano još osoba u prvom transportu. Međutim, zbog raznoraznih intervencija i grešaka koje su počinili ustaše prilikom hapšenja jedan dio uhapšenih pušten je svojim kućama. Razlozi otpuštanja iz zatočeništva bili su svakojaki. Tako je na primjer dr Daniel Rissner prešao na pravoslavlje zbog ženidbe, djeca i supruga Matije Kuzmanovića svi su katolici, Panče Tošanov je Bugarin iz Makedonije, dr Đuro Gavella je uz pomoć knjige Grci i južni Slaveni uvjerio ustaše da su Gavelle grčkog podrijetla, služavka Katica Koroš uhapšena je zajedno sa svojim poslodavcima, a ona je po nacionalnosti Mađarica, Stukalo Sergije pravoslavni je Ukrajinac i vjeroučitelj, a Ljudevit Rank je podrijetlom Nijemac čiji je otac prešao na pravoslavnu vjeru radi braka S pravoslavkom. U prvom transportu bilo je takvih 40 slučajeva (što pojedinaca, što obitelji), tj. 94 osobe. Za neke slučajeve reagirali su Slavko Kvaternik i Vjekoslav Herenčić, kako stoji uz imena uhapšenih. ${ }^{35}$ $\mathrm{Na}$ jednom malom papiru sačuvanom u fondu Državno ravnateljstvo za ponovu rukom je bilo napisano tko sve može eventualno biti pušten. Ondje je pisalo da pravoslavne "starce-samce ne treba ni hapsiti", da "miješane brakove treba puštati kućama izuzev slučaja da je isti baš posebno opasan", a također nije trebalo ni hapsiti one pravoslavce koji su prešli na rimokatoličku vjeru dok se "prijelazi na evangeličku, grkokatoličku ili starokatoličku vjeru ne uzimaju u obzir" za puštanje iz transporta ili iz logora. ${ }^{36}$

ZKRZ-ZH, kutija 486, 38503/46, C.G.K. 618/52), Mirko Dragić iz Jurišićeve 4 (HDA, ZKRZ-ZH, kutija 486, 38503/46, C.G.K. 618/53), Jovan Lončar (HDA, ZKRZ-ZH, kutija 486, 38503/46, C.G.K. 618/54)), Velimir Stanišić iz Savske ceste 13 (HDA, ZKRZ-CGK Zagreb, kutija 724, br. 301) i Đorđe Jovanović iz Hatzove 17 (HDA, ZKRZ-CGK Zagreb, kutija 724, br. 330). Jovanović je u Zagrebu ostavio čitavu stolarsku radionicu.

33 HDA, ZKRZ-ZH, kutija 621, 48200/45. Bogoljub Bratić iz Grane 61.

34 HDA, Državno ravnateljstvo za ponovu, kutija 1776, Transporti Srba iz Zagreba.

35 Isto.

36 HDA, Državno ravnateljstvo za ponovu, kutija 1776. 
U drugom transportu, koji je uslijedio 11. srpnja 1941. i koji je bio također direktno poslan u Srbiju, bilo je protjerano osamdeset osoba. Iz njega je prije progona također puštena 41 osoba (tj. 27 obitelji). Uz ovaj je transport vezana i odredba uperena protiv zagrebačkih Srba, a objavljena u Hrvatskom narodu. Svi Srbi između 16 i 60 godina morali su se prijaviti Ravnateljstvu ustaškog redarstva od 10. do 12. srpnja 1941. Ta je odredba donesena zato da bi se lakše moglo ustanoviti gdje se Srbi nalaze i da bi in se na taj način moglo lakše protjerati iz grada. ${ }^{37}$ Oni koji su navodno dali nepotpune ili netočne podatke o sebi uhapšeni su i otpremljeni u zbirne logore. Prema pisanju lista Hrvatski narod takvih je bilo $47 . .^{38}$ Prema strukturi prognanih u drugom transportu, vidljivo je da su također protjerani zaposleni Srbi. ${ }^{39}$

Treći transport uslijedio je 15. srpnja. U ovom je transportu trebalo biti prognano najviše osoba, njih 378, a uhapšenici su prisilno iseljavani preko logora u Capragu, gdje su između hapšenja i prisilnog preseljavanja u Srbiju boravili različitu dužinu vremena. I u ovom transportu su protjerani uglavnom zaposleni Srbi.

Iz ovoga transporta pušteno je čak 78 obitelji ili pojedinaca, tj. ukupno 136 osoba. Intervencije za puštanje pojedinaca i čitavih obitelji dolazile su s raznih strana. Tako je za Božidara Striku, šlagiranog poštanskog činovnika u mirovini reagirao dr Jurčić, za Dragicu Kopanju, željezničarsku činovnicu, reagiralo je Ravnateljstvo željeznica, Radomira Radonjića pustili su kao Crnogorca na temelju potvrde Crnogorskog komiteta, Matija Radoslav pušten je na temelju intervencije Slavka Kvaternika, a velik broj zatočenih pušten je na temelju činjenice da su uhapšeni dokazali da su rimokatolici ili da su prešli na rimokatoličku vjeru. Veliki broj puštenih Srba iz sva tri transporta govori o značajnosti predratnih veza koje niti novonastale okolnosti nisu mogle u potpunosti prekinuti, o nezamjenjivosti pojedinih zaposlenika, ali i o vjerojatnoj velikoj potkupljivosti ustaških organa, koji su sasvim sigurno puštali pojedince i njihove obitelji uz određenu novčanu naknadu.

Bilo je i molbi za ostanak u NDH koje su poslane neposredno nakon (istog ili sljedećeg dana) hapšenja pojedinaca. Međutim, takve su molbe bile bespredmetne ukoliko pojedinac nije imao nekoga tko bi se za njega zalagao iz ustaških redova (na prijateljskoj ili financijskoj osnovi). Tako se majka Dragislava Teodorovića, koji je uhapšen 5. srpnja 1941, uzalud pozivala na srodstvo s Lovrom Sušićem, tadašnjim

37 Hrvatski narod, br. 146, 10. srpnja 1941, str. 5.

38 Hrvatski narod, br. 155, 19. srpnja 1941, str. 16.

39 HDA, Državno ravnateljstvo za ponovu, kutija 1776, Transporti Srba iz Zagreba. 
ministrom za udružbu, i Mirkom Sušićem, tadašnjim velikim županom u Senju. Dragislav je usprkos tim jakim vezama protjeran u prvom transportu za Srbiju. ${ }^{40}$

Iz dokumenata o transportima Srba iz Zagreba moguće je ustanoviti gdje su Srbi bili nastanjeni. Statistički pregled lokacija njihovih stanova otkriva činjenicu da su ustaše uvelike u ovom prvom naletu hapsili Srbe koji su bili smješteni u dijelovima grada sjeverno od pruge. ${ }^{41}$ Uočljivo je također da su Srbi bili pretežno nastanjeni u Donjem gradu, iako ih je mnogo bilo i na Trešnjevci i Trnju. U te dvije gradske četvrti bili su nastanjeni Srbi slabijeg imovnog stanja koji su bili zaposleni kao radnici u zagrebačkoj industriji, na željeznici ili kao činovnici u državnoj upravi. Iz statističkih je podataka jasno vidljivo da je najveći broj Srba protjeran iz centra Donjeg grada. Najveći broj iseljenih stanova i kuća bio je u Ilici (23), što je i logično budući da se radi o najduljoj ulici u tadašnjem Zagrebu, potom u Palmotićevoj (15), u Deželićevoj (13), u Savskoj cesti (13), u Petrinjskoj (13) i u Kačićevoj (12). Sasvim je jasno da su Srbi iz ovih ulica protjerani ne samo radi toga što su bili Srbi već i zbog njihovog materijalno-imovinskog stanja. Ustašama su bili interesantni stanovi u centru Zagreba koji su djelomično podržavljeni, pa su u njih smješteni uredi državne uprave, a djelomično podijeljeni pojedincima koji su bili zaslužni za ustaški pokret. Jedan dio nekretnina dan je u najam za potrebe trgovine, obrta ili stanovanja.

40 HDA, Državno ravnateljstvo za ponovu, kutija 441, 314/41.

41 I u dijelovima grada koji nisu bili sjeverno od pruge bilo je nastanjenih Srba, što je vidljivo prema transportnim listama. Međutim, u dijelovima tadašnjih prigradskih naselja, tj. općinama zagrebačkog kotara bilo je izuzetno malo Srba koji su posjedovali bilo kakvu imovinu. Tako su na području Kustošije živjeli Stevan Grubić (koji je imao dvije kuće) i Dobrivoj Zlatković (koji je imao drvenu baraku), na području Remeta Nikola Rakijaš koji je imao kuću s mlinom, na području Sesveta Nikola Bunjevčević koji je imao trgovinu mješovitom robom, na području Resničke Trnave Milan Radeka koji je imao stambenu kuću, na području Granešinske Dubrave Srećko Džamonja koji je imao kuću, na području Stenjevca mlin i pilanu imao je Nikola Rakijaš (isti onaj iz Remeta), a na području Vrapča stambenu kuću Lazo Rakijaš, dok je na Jarunu dvije kuće imao Milan Lojević. Na području Brdovca, Brezovice, Markuševca, Pušće, Stupnika, Svete Klare i Zaprešića nije bilo Srba koji su posjedovali neku imovinu. (HDA, Državno ravnateljstvo za ponovu, kutija 538, 38625/41). Na području Šestina kuću su posjedovali Svetislav Gavrilović i Tošo Janjanin. (HDA, Državno ravnateljstvo za ponovu, kutija 513, 27374/41). 


\section{Molbe za ostanak u NDH upućene iz logora u Capragu}

Jedan dio uhapšenih Srba direktno je prisilno iseljen iz Zagreba u Srbiju (prva dva transporta) dok je drugi dio (treći transport) prvo odveden u logor Caprag te su odande protjerani u različitim vremenskim razmacima u Srbiju. Ni brojka od 378 (eventualno 375) prisilno iseljenih u logor Caprag ne podudara se s brojem primljenih Srba iz Zagreba u Capragu. Naime, ondje je evidentirano 365 osoba iz Zagreba koje su pristigle 17. srpnja $1941 . .^{42}$ Nakon što su uhapšeni Srbi prisilno iseljeni iz Zagreba u Caprag, jedan dio zatočenih je u onom kratkom ili dužem periodu boravljenja u logoru prije progona u Srbiju podnio molbe za neiseljavanje Zapovjedništvu logora Sisak u Capragu. U prvom mahu, 1. kolovoza 1941, radilo se o malom broju molbi (oko 200 molbi) od kojih je još manji broj poslan na razmatranje Državnom ravnateljstvu za ponovu (43), a izuzetno mali broj je pozitivno riješen (svega sedam). U drugom mahu, 22. kolovoza 1941. također je podnijet relativno mali broj molbi. Sveukupno gledajući iz logora u Capragu, prema karticama onih koji su otpušteni svojim kućama s prebivalištem u Zagrebu, otpušteno je 29 osoba. Za razliku od molbi pravoslavnih seljaka, ove su molbe pisali uvijek sami podnositelji molbe i u njima je moguće vidjeti znatno veću raznolikost u stilu pisanja i načinu moljenja.

Tako Joco Orobović, član Hrvatskog narodnog kazališta, piše molbu da ostane s obitelji u NDH, budući da se "veselio novom europskom poretku". Ujedno se "čudi što se nalazi u logoru", a ističe kako želi nastaviti svoj nastavnički posao koji obavlja već 19 godina. Vidljivo je da je molba prekasno provjerena, budući da je prije nego li je vraćena u logor Sisak Orobović protjeran u Srbiju. Na molbi je napisan niz primjedbi (izgleda idealista, eventualno pustiti, jamči ustaša Vukšec i zamjenik intendanta dr. Dulčić, te na kraju bespredmetno i otpremljen). ${ }^{43}$

Jovanka Popović, profesorica, rođena 1902. u Garešnici, također se želi vratiti u Zagreb, u svoj stan u Šubićevoj 21. Ona svoju molbu,

42 HDA, Državno ravnateljstvo za ponovu, kutija 1841, Popis unišlih u logor u srpnju 1941. godine. U prvom transportu od 1. kolovoza 1941. prisilno je iseljeno 17 Srba iz Zagreba u Srbiju, s drugim transportom 31 Srbin iz Zagreba prisilno je iseljen u Srbiju, 7. kolovoza s trećim transportom protjerano je 217 Srba iz Zagreba u Srbiju, a u četvrtom transportu 10. kolovoza 1941. protjerano je 78 Srba iz Zagreba u Srbiju. Prema tome, ukupan broj protjeranih Srba iz Zagreba u Srbiju preko logora u Capragu iznosio bi 343 osobe. (HDA, Državno ravnateljstvo za ponovu, kutija 1841, Transportne liste za Srbiju iz logora Sisak).

43 HDA, Državno ravnateljstvo za ponovu, kutija 454, 4524/41. 
kao i Orobović, piše 1. kolovoza 1941. u logoru Caprag. Ističe kako je 8. srpnja podnijela molbu za prijelaz na rimokatoličku vjeru te kako joj je taj prijelaz odobren 14. srpnja. Međutim, svega dan kasnije, 15. srpnja, Jovanka Popović je uhapšena i odvedena na Zagrebački zbor te odatle u logor Caprag. Iako se zapovjednik logora protivio njezinu puštanju, Jovanka Popović našla se među rijetkim sretnicima koji su se vratili kući. ${ }^{44}$

Molbu Ane Vujaklije iz Zagreba državni ravnatelj pozitivno je riješio te je ona puštena iz logora Caprag u Zagreb. Ona je, naime, izrazila želju da pređe na rimokatoličku vjeru, trebala bi se udati za rimokatolika, a osim toga i majka joj je rimokatoličke vjere. ${ }^{45}$

Zapovjednik logora u Capragu Sesseglia preporučio je da se pozitivno riješi molba Smilje Bjelajac, krojačice iz Zagreba, koja je također spremna prijeći na rimokatoličku vjeru te se osjeća Hrvaticom. I ta je molba pozitivno riješena, pa je Smilja Bjelajac puštena iz logora kući. ${ }^{46}$

Kući je pušten i Boško Kaporc, kojemu je samo majka pravoslavne vjere, a on je prešao na rimokatoličku vjeru. Za njega je molbu podnijela i njegova trudna buduća supruga koja ističe kako je sad "u očajnom položaju bez zaštite i bez ikoga". ${ }^{47}$

Potpuno je neshvatljivo hapšenje Nikole Kadića koji iz logora Caprag moli da ga se pusti na slobodu. On je, naime, rođen u Glamoču, ali je ostao siroče kada je imao šest mjeseci te ga je othranio rimokatolik, zagrebački stolar Fabijan Tonković. Dakako da ga je njegov hranitelj Tonković odgajao u rimokatoličkom duhu te je, prema riječima Nikole Kadića, pohađao rimokatoličku crkvu i vjeronauk. "To je dokaz da ni ja, a ni moj hranitelj uopće nijesmo ni pomišljali na to da bi ja bio druge vjere nego li katoličke, pa sam to tek pravo doznao poslije moga uhapšenja i dovođenja u ovaj logor." 48 Kadić je pušten iz logora kući.

Socijalne slučajeve poput Dragice i Jelene Antonijević, dvije sestre iz Zagreba, koje nisu na vrijeme prešle na rimokatoličku vjeru, a koje su mjesečno od socijalne pripomoći dobivale tri kilograma graha, pet kilograma brašna i koji put po kilogram šećera, a za zimu i 400 kilograma drva, ustaške su vlasti vratile kući. Iako se zapovjednik sisačkog logora protivio njihovu puštanju obje žene su puštene. ${ }^{49}$

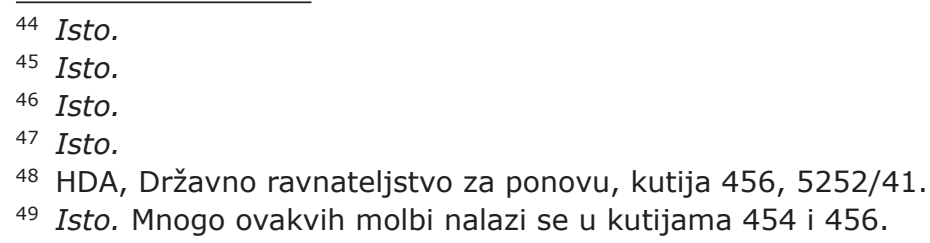


Vidljivo je, dakle, iz molbi da su parametri za otpuštanje nekoga iz logora uglavnom bili proizvoljni. Uvjet da bi netko uopće mogao podnijeti molbu čini se da je bio prijelaz na rimokatoličku vjeru ili barem najavljeni prijelaz na rimokatoličku vjeru, hrvatski korijeni jednog od roditelja ili predaka te po mogućnosti još neki drugi dobar razlog (kao na primjer trudna supruga ili zaručnica, važan položaj u poduzeću i slično). Ipak, čini se da je puštanje iz logora bilo poput igara na sreću gdje su neki uspjeli izaći, dok su drugi s istim preduvjetima za puštanje ostali u logoru i bili protjerani u Srbiju. Uspjeha su imale i molbe koje je potvrdio neki ustaša ili ustaški simpatizer, ali takvih je bilo malo, budući da su oni koji su već dospjeli do logora u Capragu uglavnom bili bez bilo kakvih veza u novim strukturama vlasti.

\section{Uvjeti života u logoru Caprag}

Koliko se čini, iz iskaza pojedinih svjedoka, u logoru Caprag nije bilo zlostavljanja zatočenika. O tome je iskaz Zemaljskoj komisiji za utvrđivanje zločina okupatora i njihovih pomagača dala Katica Brankov, inače otpuštena iz logora 22. kolovoza 1941. s pravom povrata u Zagreb. Ona je čak istaknula i dvojicu domobranskih časnika, kapetana Dogana i oficira Marinkovića, koji su, kad god je to bilo moguće, pomagali zatočenicima. U iskazu je kazala da ni zapovjednik logora Sesseglia nije zlostavljao zatočenike, a iz njezina iskaza se čini da je postojala grupna inicijativa u logoru da zatočenici koji nisu protjerani u Srbiju prijeđu na rimokatoličku vjeru i na taj način osiguraju svoj ostanak u $\mathrm{NDH} .{ }^{50}$

\section{Pojedinačna iseljavanja}

Nakon masovnih protjerivanja koja su poduzele vlasti NDH, u Državno ravnateljstvo za ponovu pristizale su molbe za pojedinačna iseljenja. Naime, velik broj Srba u Zagrebu, a posebno oni koji su radili na Državnim željeznicama, izgubili su posao, pa su uslijed nemogućnosti za zaradu u NDH preseljavali u Srbiju. Tako Marija Glumac iz Paromlinske 81, 8. kolovoza 1941, podnosi molbu za seljenje

50 HDA, ZKRZ-ZH, kutija 486, 38503/46, C.G.K. 618/41. 
svojem suprugu u Beograd koji je podnio ostavku na službi u Državnim željeznicama. ${ }^{51}$ Sve su molbe za iseljavanje bile sličnog sadržaja. Karakteristična je molba Branka Vasilića, pristava, koji moli iseljenje u Srbiju. „Kao samac u Zagrebu ne posjedujem osim mojih odjela, rublja i cipela ništa, pa molim da i ove stvari u svemu dva kofera mogu prenijeti. Sredstva za život nemam, a pošto sam pravoslavne vjere ne mogu opstati u državnoj službi te sam primoran napustiti Zagreb i potražiti sredstva za život na drugom mjestu. Otputovao bih po rješenju molbe u Beograd." 52

I obitelj Nikole Mrvoša, liječnika Središnjeg suda za osiguranje radnika u Zagrebu, dobila je dozvolu za iseljenje u Srbiju. Međutim, doktora Mrvoša uhapsili su ustaše i otpremili ga u Kerestinec, odakle je nakon neuspjele komunističke akcije proboja u srpnju 1941. otpremljen u logor Gospić (vjerojatno Jadovno). Boška Mrvoš, njegova šogorica, piše molbu da ga se iseli zajedno s njegovom obitelji u Beograd. Dakako, Boška u kolovozu 1941. godine nije mogla slutiti kakva je sudbina većine otpremljenih u logor Gospić. ${ }^{53}$

Supruga Branka Kalembera, odvjetnika, koji je bio zatvoren u Kerestincu, a potom je nestao (najvjerojatnije u logoru Jadovno), Kosara Kalember, tražila je 7. srpnja 1941, dakle nakon prvih masovnih protjerivanja Srba iz Zagreba, od Ministarstva unutrašnjih poslova dozvolu za iseljenje nje i njezine dvoje djece iz Zagreba budući da nije imala nikakve mogućnosti za održavanje obitelji. ${ }^{54}$

I Marko Džilitović, koji je u Zagrebu vodio trgovinu ženskim šeširima i priborom moli da mu se odobri da se preseli u Srbiju, gdje mu žive roditelji. On piše da mu posao vrlo loše ide, da je dužan već tri mjeseca za stanarinu, pa da se zbog lošeg poslovanja želi preseliti. Iza takve molbe zasigurno stoje brojni drugi razlozi koji su ovom čovjeku otežavali život u Zagrebu. ${ }^{55}$

Dragutin Mičić moli za iseljenje u Srbiju. On je bivši jugoslavenski oficir nastanjen u Ogrizovićevoj 2, a nakon osnutka NDH obustavljena mu je penzija, dok su njegova djeca izgubila posao. ${ }^{56}$

Interesantan je slučaj obitelji Bogdana Miljevića koja je podnijela molbu za izdavanje propusnice za iseljenje iz Zagreba u Beograd

\footnotetext{
51 HDA, Državno ravnateljstvo za ponovu, kutija 459, 6001/41.

52 HDA, Državno ravnateljstvo za ponovu, kutija 443, 923/41.

53 HDA, Državno ravnateljstvo za ponovu, kutija 457, 5411/41.

54 HDA, Državno ravnateljstvo za ponovu, kutija 444, 1184/41.

55 HDA, Državno ravnateljstvo za ponovu, kutija 444, 1523/41.

56 HDA, Državno ravnateljstvo za ponovu, kutija 444, 1321/41.
} 
početkom srpnja 1941. godine. Prije nego što su stigle spomenute propusnice, ustaške su ih vlasti pohapsile i odvele na Zagrebački zbor. Njihova rođakinja Dragica Kopanja piše dopis Ravnateljstvu za ponovu u kojem traži da se u skladu s njemačkim propusnicama dozvoli iseljenje u Beograd obitelji Bogdana Miljevića te da im se omogući da ponesu sav svoj pokretni inventar. Vidljivo je, dakle, da su oni koji su se dobrovoljno iseljavali trebali imati povoljnije uvjete za iseljavanje od onih koji to nisu dobrovoljno činili, odnosno koji su bili prognani. ${ }^{57}$

Neki su i nakon uspješnog dobrovoljnog iseljavanja ostali bez svojih stvari. Tako je Milutin Simić, djelatnik Hrvatskih državnih žeIjeznica, koji se preselio dobrovoljno 15. srpnja 1941. u Beograd putovao vlakom u vlastitom vagonu. Međutim, njegova je pokretna imovina u Zagrebu ostala zaplijenjena. Njegova majka, Ljubica Simić, moli Državno ravnateljstvo za ponovu da se Milutinu Simiću omogući da dobije natrag svoje pokućstvo budući da drugo ne može nabaviti. ${ }^{58}$

Koliko je točno pravoslavnih Srba pojedinačno napustilo Zagreb teško je ustanoviti. Međutim znakoviti su popisi koje su dostavili drugi i četvrti zagrebački redarstveni kotar početkom rujna 1941. godine. Iz tih je popisa vidljivo kako su grad napuštali ne samo pravoslavci Srbi, koji su uglavnom odlazili u Srbiju, već i Bugari i Ukrajinci, pa i starokatolici, ali i rimokatolici koji su odlazili u Italiju, Mađarsku ili Treći Reich. Svima njima je odobrenje izdalo Ravnateljstvo za javni red i sigurnost. Između 206 osoba koje su napustile grad svojevoljno prije kraja kolovoza 1941. svega je 69 osoba pravoslavne vjeroispovijesti. ${ }^{59}$ Ipak, čini se da je odlazaka Srba iz Zagreba bilo znatno više. Naime, u fondu Državno ravnateljstvo za ponovu pronašao sam dokument na kojem stoji broj „izselenih po molbi”. Takvih je, ponajviše Srba, bilo sveukupno 299. Od toga in je 252 bilo iseljeno u Srbiju, 15 u Njemačku, 15 u Mađarsku i 17 u Italiju. ${ }^{60} \mathrm{U}$ poimeničnom popisu iseljenih (koji se ne slaže s navedenim brojkama) vidljivo je da je 198 osoba najvjerojatnije (zbog činjenice da uz svaku osobu ne piše od kuda je) vezano za grad Zagreb dok su drugi dobrovoljno iseljeni (na tom popisu) vezani za Kostajnicu, Hrvatsku Mitrovicu, Sarajevo i druge gradove u NDH.

\footnotetext{
57 HDA, Državno ravnateljstvo za ponovu, kutija 444, 1221/41, 1222/41.

58 HDA, Državno ravnateljstvo za ponovu, kutija 444, 1425/41.

59 HDA, Državno ravnateljstvo za ponovu, kutija 476, 11965/41.

60 HDA, Državno ravnateljstvo za ponovu, kutija 1776, Transporti Srba iz Zagreba.
} 


\section{Pojedinačne molbe za neiseljavanje iz Zagreba}

Protjerivanjem Srba iz Zagreba nastajao je vakuum na radnim mjestima. Neka radna mjesta, poput činovničkih, obrtničkih ili željezničarskih, mogli su popuniti Hrvati koji nisu bili zaposleni ili koji su ciljano doselili u Zagreb, ali jedan dio Srba nije bilo moguće protjerati jer bi na taj način bili oštećeni hrvatsko gospodarstvo ili znanost. Tako dr ing. kemije Matija Krajčinović, predstojnik zavoda za organsku kemijsku tehnologiju na Tehničkom fakultetu, pravoslavac iz sela Jabukovac kod Petrinje koji je prešao na rimokatoličku vjeru, piše molbu da ga se ostavi na njegovu radnom mjestu te navodi niz poslova koje obavlja za Nijemce, Ministarstvo šuma i ruda i neke druge hrvatske institucije. ${ }^{61}$ Dakako, takav je čovjek potreban NDH i on zbog svoje nezamjenjivosti ne može biti prognan.

Kasno je reagirano za dr Bogdana Šolaju62 za kojeg je molbu Državnom ravnateljstvu za ponovu podnio dekan Poljoprivrednog šumarskog fakulteta u Zagrebu. Šolaja je uhapšen 10. srpnja i prognan u Srbiju 11. srpnja u drugom transportu. Dekan piše kako je „za ovaj fakultet zaslužan kako po svom naučnom, tako i nastavnom radu, jer je hrvatskom narodu odgojio niz stručnjaka". "Od sviju profesora ovoga fakulteta, on je najviše opterećeni nastavnik." Osim toga, prema pisanju dekana, po njegovoj se zamisli gradi u Maksimiru novi Kemijski zavod kojem bi Šolaja trebao biti predstojnik. Međutim, na samom je dokumentu olovkom kratko napisano odbiti. ${ }^{63}$

Za pojedine Srbe koji se uopće nisu isticali kao pravoslavci ili Srbi u međuratnom periodu molbe pišu i istaknuti pojedinci. Takvu molbu piše Zvonimir Lorković, sveučilišni profesor. Njegova intervencija odnosi se na njegove poznanike, suradnike ili prijatelje za koje ističe kako ni na koji način ne odudaraju od Hrvata i kako su odgajani u hrvatskom duhu. Tako moli za Ninu Selak, činovnicu POGODA, Dušana Bogojevića, asistenta Tehničkog fakulteta, Nadu Marjan, svršenu medicinarku, i Đorđa Bastaića, liječnika bolnice u Bjelovaru. ${ }^{64}$

\footnotetext{
61 HDA, Državno ravnateljstvo za ponovu, kutija 457, 5381/41.

62 Dr Bogdan Šolaja bio je predstojnik Zavoda za agrikulturnu kemiju od 1925. do 1939. godine. (S. Paušek-Baždar, "Bogdan Šolaja (1883.-1956.)", Udio Like u prirodnim znanostima i privredi, ur. V. Muljević, Gospić, 1978, str. 35-39.

63 HDA, Državno ravnateljstvo za ponovu, kutija 451, 3320/41.

64 HDA, Državno ravnateljstvo za ponovu, kutija 448, 2479/41.
} 
Za sebe je molbu pisao i Aleksandar Binički, redatelj i glumac Hrvatskog državnog kazališta. On moli da se na njega i na njegova dva sina ne protežu zakonske odredbe koje su propisane za Srbijnce i da ih se ne isključi iz "hrvatske narodne zajednice". ${ }^{65}$

Za četvoricu Srba reagirao je i sam Mladen Lorković. Radilo se o dr Dušanu Dokmanoviću, liječniku koji se nikada nije isticao kao Srbin, dr Gideonu Brakusu, također liječniku u bolnici Sestara milosrdnica, koji je član HSS-a od 1928. godine, i dr Stjepanu Ulmanskom, pravoslavcu, ali podrijetlom Ukrajincu, te njegovu bratu Ivanu, koji je za vrijeme Prvog svjetskog rata bio zapovjednik podmornice.

Molbe su pisali i manje značajni ljudi koji su se nadali da će uspjeti zadržati svoje trgovine, tvrtke i poslove. Veljko Bijelić, trgovac muškim odijelima, molio je također Državno ravnateljstvo za ponovu da ostane u Zagrebu. U molbi navodi da nikada nije sudjelovao u političkim organizacijama, da su mu majka i žena Hrvatice, da je uvijek glasao za hrvatske opcije, da sudjeluje u radu hrvatskih društava i slično. Svoju molbu završava rečenicom: "U Srbiji nisam nikada bio niti nikoga nemam tamo i nikada niti ne bi želio da idem tamo, jer ja osjećam da pripadam Hrvatskome Narodu i bit ću sretan, ako će mi se dati mogućnost, da ovdje sa time narodom radim, živim i da se borim u duhu današnjih državnih načela i da mi se kao takovom prizna ravnopravnost i sigurnost, kao i svima drugim spremnim Hrvatima."66

Svjesni činjenice da u Srbiji nemaju osiguranu egzistenciju, mnogi su podnosili molbe u kojima su pokušavali dokazati da sa Srbima ionako nemaju nikakve veze te da se sasvim pogrešno nalaze na ustaškim popisima Srba pravoslavaca. Za ostanak u NDH molile su i Draginja, Leposava i Sofija Gerčakov koje su na tri i pol stranice molbe isticale kako su mađarsko-češko-rumunjsko-ukrajinskog, a nikako srpskog podrijetla. Tu je molbu Draginja Gerčakov, nakon hapšenja i iseljavanja svojeg sina i snahe Aleksandra i Grete Gerčakov u Srbiju, uputila Ravnateljstvu ustaškog redarstva, koje je molbu proslijedilo Državnom ravnateljstvu za ponovu. ${ }^{67}$

Pojedini Srbi bili su zaslužni za pravašku stranku, pa su u jeku deportacija molili da budu pošteđeni od protjerivanja u Srbiju. Emil Vukašinović, član Hrvatske stranke prava od 1924. godine i podstarješina

\footnotetext{
65 MUP NDH, kutija 27, 29408/41.

66 HDA, Državno ravnateljstvo za ponovu, kutija 482, 14385/41.

67 HDA, Državno ravnateljstvo za ponovu, kutija 452, 3551/41.
} 
Hrvatskog sokola, moli 14. srpnja 1941. da ga se zaštiti kao Hrvata "od žigosanja kao Srba što sam prije bio grčko-istočne vjere". ${ }^{68}$

Neki, poput Nikole Bucala, gostioničara iz Draškovićeve ulice, bili su uhapšeni i odvedeni u zatvor u Petrinjskoj. Međutim, nakon plaćene otkupnine, pušten je kući. ${ }^{69}$

Pojedinci koji nisu bili protjerani zbog raznoraznih razloga željeli su ostati u svojim kućama. Obitelj Mihajlović Čubra, nastanjena u Strmoj cesti 55, u sjevernom dijelu grada Zagreba, moli da ih se ne iseli iz sjevernog dijela grada, u predio južno od pruge. Spomenuta obitelj bila je odvedena na Zagrebački zbor radi progona u Srbiju 14. srpnja 1941, ali su zbog prijelaza na rimokatoličku vjeru pušteni kući.

Vidljivo je, dakle, da je bilo mnogo onih koji su usprkos represivnim mjerama koje su poduzete protiv Srba željeli ostati u NDH. Nekima je kao glavni razlog poslužio posao, nekim imovina, a nekima dobra uklopljenost u zagrebačku sredinu. Strah od nepoznatog Beograda ili nekog drugog srpskog grada (ili možda još strašnije sela) kod zagrebačkih Srba bila je uvelike prisutna. Iako mnogi nisu o tome pisali u svojim molbama, vidljivo je da protjerivanje smatraju najgorom opcijom, koju na svaki način žele izbjeći. Zagrebački Srbi bili su uvelike spremni prijeći na rimokatoličku vjeru da sačuvaju svoj život, svoju obitelj, svoju imovinu i na kraju svoj položaj u društvu.

\section{Problemi nakon protjerivanja Srba iz Zagreba}

Kakav je nered nastao nakon progona Srba iz Zagreba govori dopis koji je uputila Odvjetnička komora u Zagrebu 9. srpnja 1941. godine Državnom ravnateljstvu za ponovu. Naime, kao i kod drugih zanimanja, oštećeni su u prvom redu ostali klijenti odvedenih. Tako niti jedan od privremenih zamjenika (pohapšenih i odvedenih odvjetnika) nije stekao mogućnost da na vrijeme preuzme dužnost i da se ozbiljno bavi slučajevima stranaka koje su preuzeli odvedeni odvjetnici. Naime, odvjetničke kancelarije prognanih Srba ostale su zapečaćene nakon njihova odlaska tako da su u njima ostali zatvoreni i spisi svih njihovih stranaka do kojih novopostavljeni povjerenici nisu mogli doći. ${ }^{70}$

\footnotetext{
68 HDA, Državno ravnateljstvo za ponovu, kutija 447, 2009/41.

69 HDA, ZKRZ-ZH, kutija 486, 38489/46.

70 HDA, Državno ravnateljstvo za ponovu, kutija 443, 250/41.
} 
Slično je bilo i s podržavljenim poduzećima. Tako je povjerenik Ministarstva za narodno gospodarstvo kod Glavnog saveza srpskih zemljoradničkih zadruga zatražio Uredu za ponovu da "ne iseljava ili otpušta" devet Srba, neophodnih djelatnika toga saveza. ${ }^{71}$

Vrlo se često događalo da bi nakon pečaćenja srpske imovine, tj. odvođenja vlasnika u logor, odnosno progona u Srbiju, radnici dotične tvrtke ostajali ili bez posla ili bez plaće. ${ }^{72}$ Tako se radnici tvrtke Popov i drug u Frankopanskoj 7 tuže Državnom ravnateljstvu za ponovu da su ostali bez plaće za mjesec srpanj 1941. godine. Državno ravnateljstvo za ponovu isplatilo im je spomenutu plaću. ${ }^{73}$

\section{Podržavljenje srpske imovine}

Na židovski i srpski imetak protegnuta je Zakonska odredba o imovini osoba iseljenih s područja NDH koja je donesena 7. kolovoza 1941. Prema toj odredbi sva je pokretna i nepokretna imovina iseljenih osoba proglašena imovinom NDH. Nekretnine tih osoba koje su bile namijenjene poljoprivredi ustupane su Zavodu za kolonizaciju, a stambene zgrade i poduzeća ustupale su se Državnom ravnateljstvu za ponovu. Postupak je započinjao stavljanjem napuštene imovine pod mjere osiguranja, a ukoliko se vlasnik ne bi pojavio u roku od petnaest dana, Državno ravnateljstvo je napuštenu imovinu proglašavalo vlasništvom NDH. ${ }^{74}$ Kako je to izgledalo u praksi? Nakon hapšenja pojedinaca dva izaslanika imala su zadatak da popišu cjelokupnu imovinu u stanu iseljenika, i to u dva primjerka. Originalan primjerak je slan Državnom ravnateljstvu za ponovu. Popisivana je sva imovina,

71 HDA, Državno ravnateljstvo za ponovu, kutija 461, 6666/41.

72 HDA, Državno ravnateljstvo za ponovu, kutija 1, PRS 283/41, 289/41. U spomenutim dokumentima nalazi se niz otkaza djelatnicima srpskih poduzeća u Zagrebu. Otkaz daje Državno ravnateljstvo za ponovu, a potpisuje ga Josip Rožanković, ravnatelj.

73 HDA, Državno ravnateljstvo za ponovu, kutija 452, 3712/41.

74 N. Kisić-Kolanović, "Podržavljenje imovine Židova u NDH”, Časopis za suvremenu povijest, god. 30 (1998), sv. 3, str. 438. Za Židove je u listopadu 1941. poglavnik NDH obznanio Zakonsku naredbu o podržavljenju imetka Židova i židovskih poduzeća, a 30. listopada 1942. donesena je Zakonska odredba o podržavljenju židovske imovine. Na taj je način sva židovska imovina dospjela u vlasništvo NDH. Tako nešto nije doneseno vezano za srpsku imovinu osim za imovinu solunskih dobrovoljaca. Već u travnju 1941. donesena je Zakonska odredba o nekretninama tzv. dobrovoljaca, koja se odnosila na imovinu Srba, solunskih dobrovoljaca. Prema tome zakonu sva imovina tih dobrovoljaca proglašena je imovinom NDH. 
dakle rađen je popis pokretne i nepokretne imovine. $U$ dva primjerka se sastavljao i popis stoke s podacima kome je pripadala, a potom je razvrstana po vrsti i vrijednosti. Sve prehrambene namirnice su prevožene u magazin, $\mathrm{tj}$. u mjesto gdje se nalazilo sabiralište. Imovina se iznosila iz stana i vršila se njezina procjena. Kućni inventar se stavljao u magazine - skladišta tako da bi ga zainteresirani mogli kupiti. Tako su, na primjer, posebno stavljane spavaća soba, a posebno kuhinja. Također su odvojene odjeća i obuća. Ustaške su vlasti, nakon popisivanja imovine, zapečatile stan uz prijetnju ukućanima ili susjedima kojima je predana imovina na čuvanje da oni snose moralnu i materijalnu odgovornost ako zapečaćene prostorije budu provaljene. Ključevi su ostavljani na sigurnom mjestu, najčešće u kotarskoj upravi ili u Državnom ravnateljstvu za ponovu kad je riječ o Zagrebu, a njima su mogli raspolagati samo oni kojima je imovina predana na čuvanje..$^{75} \mathrm{Od}$ 30. kolovoza 1941. godine bilo je određeno da se ključevi zapečaćenih stanova u Zagrebu predaju Gradskom poglavarstvu. ${ }^{76}$ Imovina imućnih građana bila je prva na redu za oduzimanje. Tako su oduzimane trgovačke i obrtničke radnje, industrijska postrojenja i apoteke. Poslije obavljene inventure, ta su poduzeća davana na upravu odboru od tri do pet članova na čelu kojeg je stručnjak koji je po nacionalnosti morao biti Hrvat. Ponekada nije bilo stručnjaka koji bi bio Hrvat, pa se rad u poduzećima znao i obustavljati. Zato da bi imovinu sačuvale, ustaške su vlasti postavljale privremene upravitelje na posjedima prognanih Srba. Oni su postavljani po hitnom postupku u svim bivšim srpskim poduzećima i na crkvenim imanjima, i to kako na posjedima tako i u zgradama. Privremene upravitelje su postavljale gradske i kotarske vlasti na temelju odluke Državnog ravnateljstva za ponovu. ${ }^{77}$

Nakon protjerivanja Srba i Židova iz Zagreba nastao je trenutačni vakuum u brojnim zanatima. Vidljivo je kako je Udruženje zanatlija za grad i kotar Zagreb tražilo da se što prije postave povjerenici u srpskim i židovskim radnjama. Tako su isticali kako je glavni kapital dosada bio u rukama "ne narodnih elemenata, pogotovo Srba i Židova, a to naročito vrijedi za struke krznarska, kišobranarska, stezničarska, žensko krojačka, pletačka i tkalačka..." Sada Obrtni zbor predlaže Državnom

75 Neki su od uprave nad tuđom imovinom radili business. Tako je Cvjetko Posarić iz Varšavske 2 imao upravu nad nekoliko srpskih i židovskih kuća u Zagrebu, a Državno ravnateljstvo za ponovu izvještavao je i o drugim napuštenim ili iseljenim srpskim ili židovskim objektima, o kojima je također želio preuzeti upravu uz minimalnu plaću. Posarić je naime od uprave nad tuđom imovinom živio sa ženom i troje djece. (HDA, Državno ravnateljstvo za ponovu, kutija 475, 11768/41).

76 HDA, Državno ravnateljstvo za ponovu, kutija 470, 9996/41.

77 Milošević, $n$. dj., str. 177-183. 
ravnateljstvu za ponovu da se upravo preko te organizacije postave povjerenici u židovskim i srpskim radnjama, budući da su oni najbolje upućeni u informacije o stručnjacima u pojedinim zanimanjima. ${ }^{78}$

Dobar je primjer postavljanje povjerenika u Knjižari, papirnici, antikvarijatu i trafici Ćelap na Kazališnom trgu 8. Vlasnica te tvrtke bila je Ana Ćelap, rimokatolikinja, Hrvatica iz Vrbanje kraj Županje, udana za pravoslavca. Kao povjerenik ove firme postavljen je 7. lipnja 1941. godine Ćiril Bromić, Hrvat koji je 11 godina radio kod Ćelapa. Ana Ćelap u svojoj molbi da joj se vrati Knjižara iznosi i podatke da se namjerava rastati od svojeg sadašnjeg supruga, da je prešla na rimokatoličku vjeru, da je u Kraljevini Jugoslaviji objavljivala hrvatske autore, da je zapošljavala u svojoj firmi Hrvate te da firmu namjerava dalje voditi pod svojim djevojačkim prezimenom Jurčević. ${ }^{79}$ Čest je slučaj da su povjerenici u srpskim tvrtkama bili zaposlenici tih firmi.

O neurednosti ustaških vlasti prilikom postavljanja povjerenika govori dopis koji je uputio Nikola Slavnić Državnom ravnateljstvu za ponovu. Njemu je 30. travnja 1941. godine zabranjen dalji rad trgovine koju je vodio pod imenom Malešević k.d. trgovina mješovitom robom i delikatesama u Zagrebu na Radićevom trgu 10. Odlukom Ministarstva Narodnog gospodarstva određen je povjerenik za trgovinu špeceraja i delikatesa Malešević Riste u Zagrebu Markov trg 10 koja ne postoji od 1939. godine. Budući da ista trgovina ne postoji, a u trgovini Nikole Slavnića postavljen je povjerenik bez obzira na krive podatke koji su upisani u odluci, Slavnić nije mogao trgovinu odjaviti, pa je usprkos činjenici da nije dobivao uopće novaca iz trgovine, morao platiti porez za 1941. a dolazile su mu i tužbe vjerovnika, zavoda za osiguranje namještenika i okružnog ureda. Slavnić je predlagao da se trgovina nanovo procjeni i da mu se dozvoli da je proda. ${ }^{80}$

Neki su pribjegavali lukavstvima zato da bi sačuvali svoju imovinu. Tako su Dušan i Ljubica Malbaša, vlasnici trgovine bombona u Jurišićevoj 26, odlučili da se privremeno razdvoje i to tako da je Dušan otišao voditi trgovinu u Šibenik, a Ljubica, koja je po rođenju bila rimokatolikinja, ostala je u Zagrebu voditi trgovinu u Jurišićevoj ulici. Ljubica je podnijela zamolbu Državnom ravnateljstvu za ponovu da joj se odobri da preuzme trgovinu od supruga zato da bi je mogla samostalno voditi. ${ }^{81}$

78 HDA, Državno ravnateljstvo za ponovu, kutija 443, 1042/41.

79 HDA, Državno ravnateljstvo za ponovu, kutija 513, 27375/41.

80 HDA, Državno ravnateljstvo za ponovu, kutija 525, 33180/41.

81 HDA, Državno ravnateljstvo za ponovu, kutija 475, 14430/41. 
Braća Vid i Marko Tomić, Srbi, vlasnici radnje krznarije i šešira u Marovskoj 13, oženili su jedan Šteficu Želimorski, Hrvaticu, a drugi Luizu Mihalitsch, Njemicu, te su im 18. srpnja 1941, dakle neposredno nakon velikih progona Srba iz Zagreba u Srbiju, darovali sve svoje nekretnine. U kolovozu 1941. obojica su uhapšeni, a njihova je radnja zapečaćena. Sada su obje žene podnijele molbu da se radnja otpečati budući da je ona njihovo vlasništvo, a ne vlasništvo njihovih muževa. ${ }^{82}$ Radnja je vraćena.

Malobrojni su primjeri gdje je imovina vraćena vlasnicima. Takav je slučaj frizerske radnje Ankice Majdak. I ona je, čini se, pribjegla lukavstvu. Naime, Ankica je protjerana sa svojim suprugom i djetetom u Srbiju u prvom naletu 5. srpnja 1941. U Srbiji ju je, navodno, napustio suprug, te se ona sada, kao Hrvatica vraća u Zagreb i traži svoju radnju i stan. Ankici Majdak su, uz pomoć poznanika koji su bili zakleti ustaše, vraćeni i stan i frizerska radnja. ${ }^{83}$

Molbe za vraćanje srpske imovine bile su izuzetno mnogobrojne. Najveći broj pisama Državnom ravnateljstvu za ponovu uputili su najbliži rođaci prognanih Srba. U pojedinim pismima i molbama vidljivi su i unutarnji odnosi u obitelji. Tako supruga Marka Dragosavca Sofija Dragosavac, rođena Gumze, Slovenka iz Gorice kraj Trsta, zahtijeva da joj se vrate njezine stvari iz stana na Trgu N 10 b gdje je stanovala zajedno sa svojom djecom. Nju su, iako je po rođenju Slovenka, zajedno sa djecom protjerali u Beograd. Sofija je ishodila propusnicu za Zagreb te se vratila u NDH. U pismu ona objašnjava kako je u lošim odnosima sa suprugom koji uopće ne živi s njom i kako stoga ima pravo na stvari koje se nalaze u njezinu stanu budući da će se za nekoliko dana u taj stan useliti državni uredi. Na dokumentu je vidljivo da je Državno ravnateljstvo za ponovu dalo preporuku da se Sofiju odmah potjera natrag u Srbiju, a da se molbi nikako ne može udovoljiti. ${ }^{84}$

I neki nesređeni predratni međuljudski odnosi vidljivi su iz dokumenata koje je zaprimilo Državno ravnateljstvo za ponovu Srpski odsjek. Tako je Zlata Sebastian, očito iz ljubomore, tražila da se zaplijeni čitava imovina Ljubice Martić, Srpkinje iz sela Buzeta, koja je u njezinoj kući služila kao kućna pomoćnica između 1936. i 1939. i u tome periodu postala ljubavnica njezina supruga. Suprug Zlate Sebastian, Vilko Sebastian, otišao je živjeti s Ljubicom u Klaićevu 74 i podnio je brakorazvodnu parnicu. O tome kolika je imovina Ljubice Martić Zlata

82 HDA, Državno ravnateljstvo za ponovu, kutija 457, 5516/41.

83 HDA, Državno ravnateljstvo za ponovu, kutija 466, 8454/41.

84 HDA, Državno ravnateljstvo za ponovu, kutija 459, 6073/41. 
Sebastian je doznala preko redarstvenih agenata Žitkovića i Vukelića. Ljubica Martić je bila pritvorena kod Redarstvenog ravnateljstva u Zagrebu. Dakle, vidljivo je koliko su osobni odnosi u lošim vremenima mogli utjecati na sudbinu pojedinca. ${ }^{85}$

Nekima nije imovina direktno oduzeta. Imovina Đorđa Maksimovića u Ćirilometodskoj ulici 8 bio je šesterosobni stan sa sobom i kuhinjom za podvornika te više prostorija na prvom katu spomenute kuće. Đorđe Maksimović je tražio da njegova majka i dalje ima pravo ubirati stanarinu od podstanara u ovoj kući koja joj je jedini prihod koji joj služi za vlastito izdržavanje, izdržavanje kuće i plaćanje poreza. Naime, Maksimovići su cijeli gornji kat ispraznili za državne urede, a u donjem su katu imali i dalje pravo ubirati stanarinu. Iz dokumenata nije vidljivo da li je njihova molba uvažena. ${ }^{86}$

Iz dokumenata koji su sačuvani u fondu Državnog ravnateljstva za ponovu u Hrvatskom državnom arhivu i Gradskog poglavarstva Zagreb u Državnom arhivu u Zagrebu vidljivo je kako je nakon protjerivanja Srba došlo do grabeža za njihovom imovinom. Od malih do velikih zahtjeva, od malih do velikih ljudi koji su nešto tražili. Svega nekoliko dana nakon progona Melanije Manojlović, udovice Gavre Manojlovića, nekadašnjeg predsjednika Hrvatske akademije znanosti i umjetnosti, iz njezina stana predsjednik HAZU za Akademiju traži knjižnicu nekadašnjeg predsjednika budući da se u njoj nalaze vrijedna djela koja bi mogla služiti hrvatskim učenjacima. ${ }^{87}$ I knjižnica Dušana Popovića, znamenitog zagrebačkog odvjetnika, predana je Sveučilišnoj knjižnici u Zagrebu, ${ }^{88}$ a slično je napravljeno i sa svim vrednijim predmetima (koje ustaše sami nisu za sebe rekvirirali) koji su bili predviđeni da se pohrane u Hrvatskom državnom muzeju za umjetnost i obrt u Zagrebu. ${ }^{89}$ Hrvatski državni tiskarski zavod tražio je otkup dva tiskarska stroja iz Srpske Zemljoradničke tiskare u Berislavićevoj ulici $10 .{ }^{90} \mathrm{Za}$ iste strojeve bio je zainteresiran i Gremij Grafičkih poduzeća Nezavisne Države Hrvatske koji je cijelu tiskaru želio za potrebe Grafičke škole. ${ }^{91}$ I pazikuće u srpskim kućama tražili su nakon progona Srba bolje uvjete za sebe i svoju obitelj. Tako Sofija Međurječan, koja je bila pazikuća u zgradi Olge Pavlović u Berislavićevoj 16, koja je protjerana zajedno

\footnotetext{
85 HDA, Državno ravnateljstvo za ponovu, kutija 507, 24094/41.

86 HDA, Državno ravnateljstvo za ponovu, kutija 517, 29891/41.

87 HDA, Državno ravnateljstvo za ponovu, kutija 442, 629/41; kutija 465, 8099/41.

88 HDA, Državno ravnateljstvo za ponovu, kutija 451, 3318/41.

89 HDA, Državno ravnateljstvo za ponovu, kutija 449, 2654/41.

90 HDA, Državno ravnateljstvo za ponovu, kutija 501, 21655/41.

91 HDA, Državno ravnateljstvo za ponovu, kutija 483, 14977/41.
} 
sa svojim sinom u Srbiju, traži da joj se dodijeli bolji stan u kući, pa predlaže dvosobni stan u prizemlju koji bi "odgovarao mojoj svrsi". Tvrdi da ga je i zavrijedila jer je "čistokrvna Hrvatica", kao i njezin muž, te smo "dosta prepatili za Hrvatsku" (samo ne piše na koji način). ${ }^{92}$ Sličan je slučaj i sa Leopoldom Žnidarom koji je stanovao u podrumu kuće na Trgu kralja Tomislava 10 čiji su vlasnici bili Lazo i Joco Bačić. Lazo je umro, a Joco je protjeran, pa sada Žnidar "reflektira" na stan koji je zapečaćen i njemu "neophodno potreban" budući da stanuje $s$ malim djetetom u podrumu. ${ }^{93}$ Molbe su, osim Državnom ravnateljstvu za ponovu, slane i Gradskom poglavarstvu, odnosno Stambenom uredu u Ilici 7. Takve su molbe najčešće bile vrlo sažete. Naime, u njima je bio naveden određeni stan i tražilo se da se on dodijeli reflektantu. Viktor Schulz, viši financijalni pristav, moli tako dodijeljenje stana u Mašićevoj 4, čiji je vlasnik pravoslavac Vucelić, a koji je odveden u Zagrebački zbor 14. srpnja 1941. Schulz je istoga dana podnio molbu za navedeni stan. ${ }^{94}$ Sličnu molbu šalje i Marijan Grčko, strojobravar sa suprugom i dvoje muške djece. On traži da bude upravitelj kuće u Preradovićevoj 18, koja je bila vlasništvo Srpskog Privrednika. Za posao upravitelja predlaže da mu se ustupi besplatan stan. ${ }^{95}$ Posebno često takve molbe za dodjelu stanova šalju pripadnici vojske ili mornarice i djelatnici državnih službi. Pa i pojedine državne institucije i organi traže za svoje djelatnike adekvatan smještaj. Tako Ravnateljstvo za javni red i sigurnost 21. svibnja 1941. traži od Gradskog poglavarstva - Socijalnog odsjeka da se ustašama Marku Čaviću, Stjepanu Ivandiću i Jerolimu Katiću „izda odgovarajući stan u napuštenim židovskim ili srpskim stanovima ili kućama". ${ }^{96}$ I Dragutin Jernejc, gradski senator, drsko traži „četverosobni stan u zgradi s velikim staklenim prozorima, u kraju oko Medveščaka, jer imadem malu djecu, kojoj je potreban svježi zrak". ${ }^{97}$ Takvih je molbi Stambenom odjelu Gradskog poglavarstva Zagreb poslano više tisuća, što je vidljivo prema urudžbenom zapisniku i velikom broju sačuvanih spisa.

Bilo je i sitnih krađa kao što su krađe ogrijevnog drva iz pojedinih napuštenih ili iseljenih kuća. Državno ravnateljstvo za ponovu načinilo je popis stanova i kuća u kojima su postojale određene količine uglja

92 HDA, Državno ravnateljstvo za ponovu, kutija 444, 1086/41.

93 HDA, Državno ravnateljstvo za ponovu, kutija 444, 1453/41. U kutiji 444 nalazi se posebno mnogo molbi za iseljenje.

94 DAZ, Gradsko poglavarstvo Zagreb, Stambeni ured, sign. 15, 8652/41.

95 DAZ, Gradsko poglavarstvo Zagreb, Stambeni ured, sign. 15, 8635/41.

96 DAZ, Gradsko poglavarstvo Zagreb, Stambeni ured, sign. 13, 60/41.

97 DAZ, Gradsko poglavarstvo Zagreb, Stambeni ured, sign. 13, 51/1941. 
i drva za grijanje. Na popisu se nalazilo 34 objekta. Kada je 12. rujna 1941. utvrđeno trenutačno stanje ogrijevnog drva i uglja na spomenutim lokacijama, čovjek koji je bio zadužen da to utvrdi napisao je u izvještaju da je svega na dvije lokacije ostalo drva. ${ }^{98}$ Krađe poput inventara pojedinih iseljenih srpskih stanova također su bile uobičajene. Tako je iz stana Milana Narančića u Radničkoj 29, tri tjedna nakon što je Narančić uhapšen i odveden u logor, nepoznati redarstveni agent iznio šivaću mašinu, tri velika omota u plahti, kolica za bebu, dvije bebe (igračke) i kišobran. ${ }^{99}$ Pojedinci su se zagledavali u radnje prognanih ili nestalih Srba. Tako je Pero Budimir, kojeg je dr Benzon okarakterizirao kao dobrog Hrvata i vrijednog čovjeka, zatražio od Državnog ravnateljstva za ponovu gostionicu u Gajevoj 3 koju je držao u najmu Đorđe Glišić, a koji je nestao u Aprilskom ratu. ${ }^{100}$ Isto tako je Slavko Trampetić, član Hrvatske stranke prava, zatražio pekarsku radnju Janka Pavkovića u Vodnikovoj $8,^{101}$ a Dragutin Mihaljević, električar, zatražio je da mu se da na otplatu Narodni kino na Trnjanskoj cesti kojem je vlasnik bio Rakijaš, a koji je protjeran u Srbiju. ${ }^{102}$ Posebno veliki interes postojao je za veletrgovinom engleskih štofova T.t. Anastas Pavlović, koja se nalazila u Praškoj ulici 4. Za trgovinu su molbe poslali Bojana Majnarić zajedno s Rudolfom Ljubićem, Dragutin Seljan i Ivan Maričić zajedno s Vladimirom Dvornikom. Rudolf Ljubić ističe svoje patnje koje je podnio pod kraljevskim režimom, o čemu čak donosi i potvrdu Ustaškog logora u Travniku; Dragutin Seljan traži da ga se postavi za povjerenika u spomenutoj trgovini koju je spreman i otkupiti; a Ivan Maričić i Vladimir Dvornik radili su dugi niz godina u spomenutoj tvrtki i sada smatraju da imaju pravo na prvootkup. Spomenuta dvojica imaju i preporuku Saveza hrvatskih privatnih namještenika. ${ }^{103}$ Ponekad se i među zainteresiranim stranama za neko srpsko poduzeće razvila polemika. Tako je Dragutin Mužević, dugogodišnji zaposlenik trgovine Milinov, bio zainteresiran za spomenutu trgovinu u Gajevoj. U svojem je dopisu prigovorio Zadruzi Hrvatskog radiše što dopušta da se takve trgovine dijele ne Hrvatima, tj. Slovencima „jer smo onda opet na istom kao i prije". ${ }^{104}$ I općina Šestine polakomila se za srpskom i židovskom imovinom. Općinske

\footnotetext{
98 HDA, Državno ravnateljstvo za ponovu, kutija 479, 13302/41.

99 HDA, Državno ravnateljstvo za ponovu, kutija 453, 4062/41.

100 HDA, Državno ravnateljstvo za ponovu, kutija 459, 6033/41.

${ }^{101}$ HDA, Državno ravnateljstvo za ponovu, kutija 520, 31350/41.

102 HDA, Državno ravnateljstvo za ponovu, kutija 474, 11405/41.

${ }^{103}$ HDA, Državno ravnateljstvo za ponovu, kutija 476, 11808/41.

104 HDA, Državno ravnateljstvo za ponovu, kutija 455, 4874/41.
} 
vlasti predlažu da se nova općinska zgrada sagradi od novca koji bi se dobio prodajom srpskog i židovskog zemljišta na području općine. ${ }^{105}$

Bilo je i očitih nasilnih prisvajanja tuđe imovine. Tako je bilo $s$ Ritz barom kojem su vlasnici bili Židov Artur Glueck i pravoslavni Mađar Đorđe Suvajdžić. Glueck je nakon osnutka NDH napustio područje Zagreba, pa su bar vodili Đorđe Suvajdžić i njegova supruga Štefanija. Na mjesto Gluecka Suvajdžić je prihvatio Jure Bušića, koji se iskazivao kao ustaša, koji je dobio od gradskog obrtnog odsjeka obrtnicu da vodi Ritz bar. Zaradu su trebali dijeliti pola-pola. Suvajdžića su ustaše uhapsili 13. srpnja 1941. i prognali u Srbiju. Nakon toga je Bušić na silu zabranio Štefaniji Suvajdžić da ubire dobit. Štoviše, iako je ona po nacionalnosti bila Njemica, prisilio ju je da mu preda ključeve od bara i sav novac koji se nalazio u kasi. Štefanija Suvajdžić se žali Državnom ravnateljstvu za ponovu da su ona i suprug "postupkom Bušićevim protuzakonito potpuno uništeni". ${ }^{106}$

Imovinu koja je ostala u NDH prognanima gotovo nikada nije uspjelo vratiti. Brojne su molbe iz Beograda slane u Zagreb Državnom ravnateljstvu za ponovu da se vrate pojedine stvari, predmeti iz kuća, a ponekad i nekretnine, ali državne su se vlasti redovito oglušile na te pozive. Karakterističan je i dirljiv slučaj Dušana Stojanovića koji je prognan iz NDH zajedno sa svojom djecom i suprugom. On iz Beograda, mjesec dana nakon progona, očito bez ikakvih mogućnosti zaposlenja, bez primanja, smješten kod poznanika, fizički i duševno potpuno uništen, moli da ga se vrati na posao u Hrvatske državne željeznice u Zagreb, a ukoliko to ne može, barem da mu se predaju stvari koje su ostale u njegovoj kući u Trebinjskoj 3. Na kraju, zapravo beznadno, moli da njegovom bratu, koji je ostao u Zagrebu, predaju makar posteljinu i odijela. ${ }^{107}$

Krajem studenog i početkom prosinca 1941. Privredni odio Državnog ravnateljstva za ponovu izvlastio je niz srpskih poduzeća. ${ }^{108}$ Krajem prosinca načinjen je drugi popis na kojem se vidi u koja su srpska poduzeća postavljeni povjerenici, tj. poduzeća koja je preuzelo Državno ravnateljstvo za ponovu. Takvih je poduzeća bilo 29. ${ }^{109}$ Prema popisu koji je načinilo Državno ravnateljstvo za ponovu 14. listopada 1941. u Zagrebu je čak 95 srpskih poduzeća bilo podržavljeno.

\footnotetext{
${ }^{105}$ HDA, Državno ravnateljstvo za ponovu, kutija 513, 27374/41.

${ }^{106}$ HDA, Državno ravnateljstvo za ponovu, kutija 502, 21984/41.

${ }^{107}$ HDA, Državno ravnateljstvo za ponovu, kutija 455, 4800/41.

${ }^{108} \mathrm{HDA}$, Državno ravnateljstvo za ponovu, Privredni odio, kutija 604.

${ }^{109}$ HDA, Državno ravnateljstvo za ponovu, kutija 547, 42924/41.
} 
Nažalost, ta nam poduzeća nisu popisana. ${ }^{110}$ Prema popisu Državnog ravnateljstva za ponovu likvidirano je 111 srpskih poduzeća u Zagrebu, ali se čini da je jedan dio njih prestao nakon likvidacije funkcionirati. ${ }^{111}$ Prema popisu srpskih zgrada u gradu Zagrebu vidljivo je da je njih 86 pod upravom Privrednog odjela Državnog ravnateljstva za ponovu. ${ }^{112}$ Ustaške su vlasti popisivale i sve novčane uloge Srba koji su živjeli u NDH. Tako je Savez novčanih i osiguravajućih zavoda NDH popisao sve Srbe koji su posjedovali bilo kakve uloge u bankama. Dakako da je tim novcem raspolagalo Državno ravnateljstvo za ponovu. ${ }^{113}$

\section{Zaključak ili bilanca prognanih}

Točan broj prognanih Srba iz Zagreba nemoguće je ustanoviti. Međutim, postoje dobri pokazatelji koliko je Srba iz Zagreba 1941. godine moglo biti prognano što u masovnim transportima što pojedinačno. Samo poimenični popisi mogu dati približan broj protjeranih Srba iz Zagreba. Oni su djelomično sačuvani u Hrvatskom državnom arhivu u fondu Državnog ravnateljstva za ponovu. Međutim, oni su već u svojem startu nepotpuni, a ponekad i pogrešni. U svakom slučaju tek djelomična njihova sačuvanost upućuje nas da je prognanih bilo više nego što je to u popisima navedeno. Dana 20. rujna načinjen je sumarni popis prognanih po kotarevima te je iz njega vidljivo da je do toga dana, prema evidenciji Državnog ravnateljstva za ponovu, iz grada Zagreba bilo protjerano 1.110 Srba (bez pravoslavnih svećenika). Taj broj je vrlo blizak broju do kojeg dolazimo zbrajajući tri transporta iz Zagreba u Caprag ili direktno u Srbiju koji iznosi $(261+80+343)$ osoba te $267(198+69)$ pojedinačnih prognanika iz Zagreba u Srbiju, Italiju, Treći Reich i Mađarsku. Dakle, ukupan poimenični popis protjeranih može obuhvatiti 951 osobu. Evidentno je da taj popis nije potpun i da je prognanih u svakom slučaju bilo više. ${ }^{114}$ Što se srpske imovine tiče,

\footnotetext{
${ }_{110}^{110 A}$, Državno ravnateljstvo za ponovu, kutija 504, 22697/41.

${ }^{111}$ Državno ravnateljstvo za ponovu, Poduzeća, Kazalo - srpske radnje u likvidaciji 1941 A-Ž, knjiga 173.

112 HDA, Državno ravnateljstvo za ponovu, kutija 504, 22697/41.

${ }^{113}$ HDA, Državno ravnateljstvo za ponovu, kutija 460, 6403/41.

${ }^{114} \mathrm{U}$ popis tako na primjer nisu uopće uračunati ilegalni iseljenici, tj. oni koji su otišli iz Zagreba ne javivši se državnim vlastima. Zato da bi izbjegli progon iz grada Zagreba, pravoslavni su masovno prelazili na rimokatoličku vjeroispovijest. Manji je broj onih koji su prešli na grkokatoličku vjeroispovijest, a još manji broj onih koji su prešli na starokatoličku vjeroispovijest, evangeličku vjeroispovijest i islam. Prema
} 
iz dokumenata je vidljivo da je ona bila velikim dijelom podržavljena, ali da su pojednci, uz pomoć prijateljskih i poslovnih veza, uspijevali zadržati svoju imovinu. Razmjere podržavljenja te imovine nije u potpunosti moguće utvrditi, ali ako je vjerovati statistikama koje su provele državne vlasti, čini se da je najmanje 95 srpskih poduzeća i 86 srpskih zgrada u Zagrebu bilo podržavljeno.

\section{Summary}

Filip Škiljan, Ph. D.

\section{Expulsion of Serbs from Zagreb and Confiscation of their Property in 1941}

Key words: World War II, 1941, Serbs, Independent State of Croatia, Zagreb, concentration camps

The Orthodox population of Zagreb numbered 13279 people (7.2\%) according to the census of 1931 . In the first period after the founding of the Independent State of Croatia, the Ustaša regime wanted to take revenge on all "enemies" who in any way took part in or supported the former monarchist regime and were "enemies of the Croatian people". The first to be persecuted by the Ustaša regime were the Serbs. The actual preparations to expel the Serbs from Zagreb were made after passing Legislative provisions for the protection of people and state, legislative provisions banning the use of Cyrillic alphabet,

evidenciji vjerozakonskih prijelaza samo je na području Zagreba između 1941. i 1945. izvršeno 7.070 (od toga 6.714 između 1941. i 1943, 275 u 1944. i 81 u 1945. godini) vjerozakonskih prijelaza. Od toga ih je, koliko sam ih ja izbrojio, bilo 3.385 prijelaza s "grčko-iztočne", odnosno "pravoslavne", "bugarsko-pravoslavne", "pravoslavno-istočne", odnosno "rusko-pravoslavne" vjeroispovijesti na neku drugu vjeroispovijest. Od toga in je svega 24 bilo u 1944. i 8 u 1945. dok su između 1941. i 1943. izvršena 3.353 vjerska prijelaza. Prijelazi s rusko-pravoslavne i bugarskopravoslavne vjeroispovijesti dosežu brojku od svega dvadesetak osoba. (HR-DAZG - 24 GPZ, politički odsjek, Polit 14, Iskaz vjerozakonskih prijelaza (1941- )). Prvi vjerski prijelaz s pravoslavne na rimokatoličku vjeroispovijest u NDH izvršen je 15. travnja 1941. kada je Viktor Višnovac primljen natrag u rimokatoličku vjeroispovijest. (NAZ, Registar Nadbiskupskog duhovnog stola za 1941. godinu, 3616/41). 
legislative provisions on converting from one religion to another and use of hate speech that was so widespread in the media and public Ustaša assemblies. The preparations were arranged with the representatives of the German authorities in June. Ustaša authorities made a list of Serbs and then the expulsion of 684 people from Zagreb to Serbia was conducted in three waves while 267 people individually left Zagreb for Serbia. Serbs arrested in the first two waves were expelled directly to Serbia, while Serbs who remained for the third wave were deported first to the Caprag camp and then 343 of them to Serbia. A small number of Serbs managed to leave the Caprag camp by submitting pleas. It is evident that this list is not complete and that the number of expelled Serbs was larger. As far as Serbian property is concerned, documents show that it was largely confiscated by the state, however some individuals through business or friendly connections, managed to keep their property. It is not possible to establish the extent of confiscated property, however the government statistics show that at least 95 Serbian companies and 86 Serbian buildings in Zagreb were confiscated. 